Mukaddime, 2019, 10(2), 619-642

DOI: 10.19059/mukaddime.549048

\title{
Hayali Bey Divanı'nda Poetik Söylem Bağlamında Tefahür
}

\section{Kenan Bozkurt' - Tuba Bezenmiş}

Öz:Klasik şiiri Fars edebiyatı seviyesine getirme hususunda emeği inkâr edilemeyen Hayâlî Bey, Kalenderî grubuyla adım attığı İstanbul'da şairlik dehasıyla kendini ispatlamış, devlet ricalinin hamiliğini kesp ederek klasik şiirin zirve şahsiyetlerinden birisi olmuştur. Sanatçı kişiliği, çağdaşları tarafından takdir edilerek "sultânü'ş-şuârâ-yı Rûm" unvanıyla onurlandırımıştır. Ancak şair, Osmanlı patronaj geleneğinin bir gereği olarak söz söylemedeki ustalığını, şairlik dehasını kasidelerin fahriye ve gazellerin makta bölümünde ortaya koyarak tefahürde bulunmuştur. Aslında bu bölümler, şairin kendisini övmesi için uygun bir fırsatın yaratıldığı bölümlerdir. Bu bölümde şair, şairlik kudretinden, erdemlerinden, ne kadar usta bir şair olduğundan abartılı bir şekilde bahseder ve kendisiyle diğer şairler arasında bir mukayeseye girerek üstünlük iddiasında bulunur.

Bu çalışmamızda Hayâlî Bey'in Divânı, tefahür bağlamında taranarak şairin tefahürde bulunduğu beyitler tespit edilmiş ve bu beyitler, şairin poetik söylemi bağlamında incelenmiștir.

Anahtar Kelimeler: Hayâlî Bey, Divân, Gazel, Kaside, Tefahür.

\footnotetext{
${ }^{1}$ Dr. Öğr. Üyesi, Batman Üniversitesi, kenan.bozkurt@batman.edu.tr, ORCID No: https://orcid.org/0000-0002-52270614.

${ }^{2}$ Batman Üniversitesi Sosyal Bilimler Enstitüsü Yüksek Lisans Öğrencisi, bezenmistuba@gmail.com, ORCID No: https://orcid.org/0000-0002-9686-5839.
} 


\title{
Boasting in the Context of Poetic Discourse in the Divan of Hayali Bey
}

\begin{abstract}
As one of the celebrated poets of his time, Hayalî Bey whose effort to bring the classical poetry to the level of Persian literature cannot be denied. By stepping with a Kalender group in Istanbul, he proved himself with the brilliance of poetry and became one of the most prominent figures of classical poetry by obtaining the patronage of the state dignitaries.The poet, who has a wise and creative artistic identity, was honoured by his contemporaries for his success in the arts with the title of "sultânü's-şuârâ-yı Rûm". However, as a requirement of the Ottoman patronage tradition, the poet boasted of himself by revealing his eloquence genius in the eulogy chapter of the odes and in the ending grain chapter of the ghazals. In fact, these chapters are parts where a suitable opportunity has been created for the poet to boast of himself. In this chapter, the poet, by exaggeratedly mentioning his ability, virtues and what a master he is, claims superiority by making a comparison between himself and other poets.

In this study, the concept of boasting has been discussed, the whole poetry of Hayali Bey and the chapters about the poesy of the poet with regards to boasting have been examined.
\end{abstract}

Key words: Hayali Bey, Divan, Ghazal, Ode, Boasting.

\section{Giriş}

Arapça olan 'tefahür' sözcüğü, 'f-h-r' kökünden türetilmiş olup sözlüklerde övünme, kurulma, iftihar, kibirlenmek, kibirli olmak, böbürlenme, gurur, büyüklük, büyüklenme, şeref, onur, kıvanç, ululuk, şöhret, ün, fazîlet, erdem, kendisiyle övünen kişi (Kanar, 2009: 928; Develioğlu, 2013: 284; Parlatır, 2009; 433; Çağbayır, 2007: 1539; Ayverdi, 2011: 928; Güneş, 2010: 879) gibi anlamlarla yer almaktadır. Tefahür sözcüğüyle aynı kökten gelen "fahriye" sözcüğü ise edebi bir terim olup klasik şiirde şairlerin kendi faziletlerini ve üstünlüklerini övmek, kendisiyle övünmek için yazdıkları şiirler; kasidenin bir bölümüne veya övgü kısmına; mesnevi, gazel ve kaside gibi türlerde şairin kendini övdüğü, felekten yakındığı; durumunu eseri sunduğu kişiye ilettiği bölüme (Parlatır, 2009: 433; Develioğlu 2013: 284; Komisyon, 2005: 676; Dilçin, 2009: 266; İsen: Fahriye, 2013) verilen addır.

Klasik edebiyatta şairlerin fahriyeleri, abartılı övünme edası taşır. Daha çok kasidenin bir bölümü olarak başkalarının övgüsü esnasında kaleme alınsa (Dilçin, 2009: 266; T. Mevlevî, 1994: 43) da gazellerin mahlas beyti ve mesnevilerin sebeb-i telif bölümleri de şairlerin tefahürde bulunduğu 
bölümlerdir. Bu bölümler, şairi tanıtma amaçlı olduğu gibi şairin kendini diğer şairlerle kıyaslayarak üstün olduğunu iddia ettiği ve bunu abartılı ifadelerle dile getirdiği, daha çok şiirdeki ustalığından bahsettiği bölümdür (Pala, 1995: 177; Andrews, 2009: 206). Şairler, kendilerini överken daha ziyade şiirdeki kudreti, tab’ı, nazmı, inşası, kalemi, sözde kendisine nazir olamayacağı gibi hususiyetleri dile getirir ve kimisinde de belli şahsiyetleri hedef alarak yerer (Kaçar, 2006: 105). Bu övgüde esas olarak iki yön ortaya çıkar: Şairler, kendilerini ve sözlerini ya "tutî-i mûcize-gû, Îsî-dem, silk-i teşbih-i dür-i seb’ul-mesânî" gibi harikulade vasıflarla tavsif ederek övünmüşler yahut da Arap, Fars ve Türk şairleriyle kendilerini mukayese ederek daha üstün olduklarını iddia etmişlerdir (Levend, 2017: 554).

Fahriye, ilk kez Arap şiirinde fahr veya iftihar adıyla ortaya çıkmış ve klasik kasidede medhiye bölümü ile birlikte kasideye hüviyetini veren asıl bölüm olarak yer almıştır (İsen: Fahriye, 2013). Yıpratıcı kabile savaşları ve şairler arası çekişmenin bir sonucu olarak İslam öncesi Arap edebiyatı geleneğinin bir parçası olan 'fahriye',Cahiliye şiirinin asıl konuları içinde yer alır. Zira övmek/medh ve övünmek/fahr, Cahiliye kasidesinin mühim konularındandır ve methedilen şahsın övülmeye değer vasıfları olan cesaret, kahramanlık, iffet ve adalet gibi sıfatların şiirde övülmesi esastır. Şairler, fahr yaparken muhitin önemli vasıflarından olan cömertlik ve cesaret üzerinden kabilesini övmüştür. Emeviler döneminde büyükleri övmek maksadıyla kasideler yazılmıştır. İhsan almak amacıyla yazılan kasideler, müspet bir etki yaratmıştır ve devlet adamlarına kaside yazılmasını sağlamıştır (Çetin, 2011: 72-73). Arap edebiyatında olduğu gibi İran edebiyatında da şairler tefahürde bulunurken Arap edebiyatının benzer motiflerinden yararlanarak kendilerinin ne kadar iyi bir hatip olduğunu Arap şiirinin önemli hatip ve şairleriyle dile getirmişlerdir (İsen, 2002: 12-13).

Klasik şiirde şairlerin eserlerinde ya da eseri takdim ettiği kişileri överken kendi sanatçı kimlikleriyle övünmelerinin bir gelenek olarak algılanması gerektiğini göstermektedir (Kaçar, 2006: 106). Âcz ve fakr kültürü ile zıddıyet içerisinde olan fahriye, Osmanlı klasik şiirinde 14. yüzyılda görülmeye başlanmış ve 15. yüzyıla kadar şairler, kendilerini överken aynı zamanda da memduhunu da dolaylı yollardan övmekteydi. Bu dönemin önemli hususlarından biri, şairlerin şiirlerinde memduhları karşısındaki konumlarını her fırsatta açık bir şekilde belirtmesidir. Şairin temel amacı, fahriyelerinde kendini yüceltmek olmayıp memduhundan bir şey talep etmek, içinde bulunduğu hâli aktarmaktı (İsen: Fahriye, 2013). 15. yüzyılın sonuna kadar fahriyenin asıl özelliklerini yansıtmadığını söyleyebiliriz (Karadeniz, 2012: 1651). Zira bu yüzyılda şairler kendini övüp göklere çıkarmak yerine şair kimliklerine vurgu yapmayı daha yerinde görmüş ve çoğu kendilerini güzel konuşma hasebiyle "tûtî"ye benzeterek şiirlerindeki sözlerin "gevher” olduğunu dile getirmişlerdir. Ancak Fatih’le teşekkül etmeye başlayan yeni nizam ve saray muhiti, şairler için şiirin hitap ettiği memduhun ve şiirin gayesinin de değişiminin habercisi olmuştur. İyi eğitim almış, şiirden anlayan, iyi ve kötü şiiri birbirinden ayırabilen iktidarın mutlak gücüne yakın olmak bir 
ayrıcalık haline gelmeye başlamıştır. Buna bağlı olarak da mutlak iktidar sahibine yaklaşmak, şairliğin kudretine bağlı olduğundan şair, bu kudretini her fırsatta dile getirmekten geri kalmamıştır. Sanatını padişahın takdirine sunan şair, takdire nail olmak için kendini çağdaşlarından ya da Arap ve Farsların büyük şairlerinden daha üstün olduğunu vurgulamayı şiirin bir parçası saymıştır.

17. yüzyıl fahriyeler açısından bir dönüm noktası olup Nef’î ile fahriye zirve yapmıştır. Zira Nef'î gibi büyük bir şairin elinde fahriye yepyeni bir boyut kazanmış, şair fahriyeyi neredeyse şiirin ana unsuru olarak ele almıştır. “Kendisinden üstün şair tanımayan Nef'î, şiirlerinde 'ben' zamirini çok fazla kullanan ve bu yönüyle de diğer şairlerinden ayrılan bir özelliğe sahiptir. Şairin gazellerinin 29'u 'ben' zamirinin ön planda olduğu kafiye ve rediflerden oluşmaktadır. Devlet büyüklerini methetmek amacıyla yazdığı kasidelerinde bile, şairin asıl maksadı kendisini övmektir. Kasidelerinde, methettiği kişiyle âdeta karşılıklı konuşur gibi tabii bir ifade sergileyen şair, hemen her fırsatta kendisini anlatarak asıl konu ve dikkati kendi üzerinde toplar" (Bilkan, 2007: 143-144).

Muhsin Kalkışım, klasik edebiyatta 'ben' merkezli bir şiirin doğmasını Sebk-i Hindî etkisine bağlar (2010: 146). Zira Sebk-i Hindî üslubu, şairin iç dünyasını önemseyerek şairin psikolojisine dair unsurların şiire girmesini sağlamıştır. Bunun sonucu olarak da klasik şair, orijinali yakalamaya çalışırken 'benlik' duygusunun labirentlerinde mahsur kalabilmekte, kendisine verilen sınırlı; ama hesaba gelmez keyfiyetlerle ilişkili olan yeteneklerini kullanırken psikolojik vartalara düşebilmektedir. Bu da fahriyenin önceki dönemlere kıyasla çok çeşitli hayallere, girift mazmunlarla ele alınmasını ve şairin benlik duygusunun fahriyeye yansımasını mümkün kılmıştır. 18. yüzyıl örnekleri sayıca fazla olmamakla birlikte fahriyeler açısından mühim misaller verilmiştir (İsen, 2002: 38).

Osmanlının edebiyat, sanat ve kültür muhiti; şan, şeref sahibi olmak için sanatkâr ve seçkin bilim insanları, bir patrona ihtiyaç duyduğundan fahriye, Osmanlı patronaj sisteminin bir gereği olup sarayla evirilmiştir. Osmanlı patrimonyal içtimai düzende terbiyet, kulluk, intisap sosyal ilişkilerin temeli hâline gelmiş; patron, şöhret ve mevkiini yüceltmek amacındayken kul ise hayatta kalma ve ilerleme mücadelesi vermekteydi (Inalcık, 2018: 14). Bu da şairlerde saraya yaklaşma hususunda ciddi bir çabanın başlamasına neden olmuş; birçok şair, devlet ricâlinin himayesini kazanmak amacıyla kasideler yazmıştır. Hâmî arayışı ve lütfa erme kastı dönemin şairleri arasında bir rekabet ortamı da yaratmıştır (İnalcık, 2018: 14). Bu rekabetin sonucu olarak şairlerin kendi şairliklerine dair iddialarda bulunmalarının önünü açmış, şairlik kudretini pazarlamak amacıyla abartılı söylemleri dile getirmelerine neden olmuştur.

Fahriye bölümünde şairin bu tarz iddialarda bulunmuş olması, aslında şairin övdüğü kişiye bir münasebetle kendi halinden, maddi sıkıntılarından, hak ettiği halde himâye görmeyişinden söz ederek dolaylı olarak maddî ve manevî yardım istediğini hissettirme amaçlıdır (Çavuşoğlu, 1986: 22). Şairler, hünerlerini 
gösterme peşinde olduklarından kendilerini başka şairlerle mukayeseye etmiştir. Bu kıyaslama bazen kendi dönemlerindeki şairlerle bazen kendinden önce yaşamış meşhur şairlerle yapılmıştır. Doğaya dair unsurlar, dinî motifler, aşk kahramanlar da fahriyelerde mukayese unsurudur ve bütün bu benzetme ve nitelemeler, ideal şairin portresi ortaya çıkmak amacıyladır (İsen, 2002: 64). Fahriye bölümlerinde şairin kendi şairliğine yaptığı abartılı övgü, şairin gerçek kimliğini, dehasını yansıtmaz; aslında ideal olana göndermede bulunur. Bu yaklaşımı, ideal şiirde bulunması gereken vasıfların ne olması gerektiğine yöneliktir ve şair, olağanüstü vasıflarla övdüğü şiirinde övülen vasıflar yoksa da ideal bir şiirde bulunması gereken hususları ortaya koymuş olur.

\section{Psikolojik ve Dinsel Açıdan Tefahür}

Bilinçaltı birikimleri, sosyal çevre, sosyal bilinç, toplumsal faktörler ve dinamikler insanın kişiliğini oluşturduğu gibi bu etkenler; aynı zamanda şairlerin poetikalarını ve şiir yazma nedenlerini de oluşturur. Klasik şiirde sedefin içine ebri nisandan düşen her katrenin sedefte yarattığı sancıyla incinin ortaya çıkışına dair anlatılan efsane, şairin şairlik sürecinde yaşadığı yaratma sancılarının sembolik ifadesidir. Eser oluşturma süreci, her ne kadar sanatsal dehanın, içsel huzursuzluğunun ürünü olsa da bu süreç, içinde bir şekilde şişik bir egoyu, megaloman ve narsistik bir kişiliği de barındırır. Karen Horney, narsistliği tanımlarken narsistik olguları arasında "kibir, bencillik, prestij ve hayranlık özlemi, sevilme arzusu ve bununla birlikte başkalarını sevme yetisinden yoksunluk, insanlardan uzaklaşma, normal özsaygı, idealler, yaratıcı arzular, sağlığa, görünüșe, entelektüel becerilere yönelik kaygılar" gibi özellikleri (1994: 64) saymaktadır.

Horney'in narsistik kişilik için yaptığı değerlendirmelerin temel özelliklerin birçoğunu, klasik şairlerin fahriyelerinde görmek mümkün olduğundan klasik şairin kişiliğinde mütevazılık aramak, onun kendisini inkâr etmesi anlamına geleceğinden klasik şairler, kendini her zaman toplumdaki kişilerden, diğer sanatçılardan üstün görür ve sanatı ile övünmeyi neredeyse büyük sanatçılığın bir gereği sayar (Kaçar, 2006: 109). Bu yüzden klasik şairler; şiirdeki hünerini en büyük şairlerle kıyaslarlar, yeri gelir âşıklık konusunda Mecnun'dan daha iyi olduğunu dile getirirler, sözlerini hazineden çıkarılmış inciye benzetirler ve en iyi olma yarışında bu söz meydanında diğer şairlerden üstün olduğunu iddia ederler. Tüm bunlar, şairin kendini kabul ettirme çabası içinde olduğuna işaret olsa da onların narsistik kişiliklerinin dışavurumunun bir sonucudur da. Çünkü klasik şair, narsisizmin temel eğilimlerinden olan "hiç kimse beni olduğum gibi sevmez" cümlesini yaşadığı toplumsal dönemi de göz önüne alarak "hiç kimse beni bu şekilde fark etmez" cümlesine dönüştürür (İsen, 2002: 14). Bu yüzden fahriyenin şairlerin içinde bulundukları ruh hâlinin bir parçası olduğunu göz önünde bulundurmak gerekir.

Yukarıda şairlerin tefahür boyutunun psikolojik temelleri üzerine yaptığımız kısa değerlendirmeyi çalışma konumuz olan Hayâlî örneği üzerinden değerlendirdiğimizde konu daha iyi anlaşılacaktır. Zira Hayâlî, küçük yaşta bir 
Kalenderî şeyhinin büyüsüne kapılarak geldiği İstanbul'da hayatı için bir dönüm noktası olmuş hem güzelliği hem de zekâsıyla dikkatleri üzerine çekmeyi başararak devlet erkânı tarafından himaye edilmesiyle erken yaşta şiirde şöhret bulmuş, şiirdeki kudreti sayesinde devletin en üst kademelerindeki idarecilerin takdirini kazanmıştır. İbrahim Paşa Hayâlî’yi padişaha tanıtmakla Kanûnî'nin iltifatını ve himayesini kazanmasına ve böylece padişahın şaşalı muhitine girmesine vesile olmuştur. Kendisine ulufe bağlanılmış, padişahın musahibi ve nedimi olmuştur. Yakaladığı şöhret, devrin diğer şairlerinin haset duymasına neden olmuştur. Hayâlî’nin sanatçı kimliğiyle elde ettiği başarı, başta Zatî, Yahya Bey, Kandî, Keşfî, Hasbî, Basirî, Selikî gibi devrin diğer şairlerinin şimşeklerinin Hayâlî'nin üzerine çekilmesine neden olmuş ve tenkide maruz kalmıştır (Ipekten, 2002: 96). Zira duyulan haset, arzulanan bir şeyin başka birine ait olduğu ve bize değil de ona haz verdiği inancının yol açtığı kızgın bir duygudur; haset itki, o istenen şeyi sahibinden çekip almaya ya da bozmaya, kirletmeye yönelir (Klein, 2008: 23). Hayâlî̉nin sahip olduğu konumun etkisiyle şairlerin haset ettikleri varsayımından yola çıkarak şöyle bir yorumda çıkarılabilir: Hayâlînnin kendi bulunduğu konumu muhafaza etmek amacıyla içinde bulunduğu halet-i ruhiyesi kendisini bir başka şairle kıyaslamaya sevk etmiştir.

Tefahürün psikolojik bir izahı olup mazur tutulacak tarafları olsa da dinî gelenek -Şuara suresinin şaire bakışını da göz önünde bulundurursak- bir kimsenin kibirli davranışına, tekebbürlük edişine pek de sıcak bakmaz. Kur'an'da Allah'ın sevmediği fiiller arasında kabul edilen, günümüzde bir ahlâk ve psikoloji terimi olarak kullanılan egoizm ve kendini üstün görme, dolayısıyla kendini her şeyin amacı olarak kabul etme eğilimi (egosantrizm) anlamındaki enâniyeti yeren pek çok ifade bulunmaktadır. Mesalâ Firavun'un çılgınca bir bencillik duygusuyla halkına, "Ben sizin en yüce tanrınızım." (en-Nâziât 79/24) demesi, Kârûn'un azgınlıktan kaçınma ve insanlara ihsanda bulunma yönündeki tavsiyelere karşılık elindeki bütün imkân kendi bilgisiyle kavuştuğunu iddia etmesi(el-Kasas 28/7679) Kur'ân'da şiddetle eleştirilir.” (Hökelekli: Enaniyet, 1995). Benzer eleştiriyi sufî gelenekte de görmekteyiz. Sûfîzmin temel amacl "kültürel benden kurtulup kozmik bene varış" (Sayar, 2000: 46) olduğundan insanın benliğini yüceltmesini, bu süreçte olumsuz bir davranış sayar. Zira sûfî gelenekte insan benliğine kimi zaman ene kimi zaman nefs kimi zaman da rûh/cân kavramlarıyla atıfta bulunulmuştur” (Küçük, 2009: 43). "Mutasavvıflar genellikle kötülenen ve aşağılanan, diğeri övülen ve yüceltilen aşkın/müteal olmak üzere iki 'ene'den söz etmişlerdir. Ene/ben kelimesi, bir insanın “ben” diye söze başlayıp kendisini övmesi ve öne çıkarması, ahlâkî anlamda kötü bir davranış olarak görülmüş, "ben” demenin iblîs'e özgü bir davranış olduğu belirtilmiştir" (Uludağ: Ene, 1995). "Ben kelimesi tasavvufî edebe ve nezakete uygun düşmediğinden sûfîler sahip oldukları şeyleri kendilerine nispet edip 'evim, seccadem' yerine 'evimiz, seccademiz' demeyi tercih ederler. İbrahim b. Şeybân'ın 'ayakkabım, ibriğim' demeyi enâniyet saydığı, böyle söyleyenlerle sohbet etmediği rivayet edilir" (Uludağ: Ene 1995). Mevlânâ da Mesnevi'de "bedene perestiş eden kullar"dan ve 
“ bedene bağlılık ipini koparanlar"dan söz eder (Mevlana, 2013: 296). "Insanı kendi sonsuz benliğine götürmesi gereken akıl ve temyiz yetisi, insanı sonsuz benliği ile yüzleştirmek yerine, onu elindekiler ile övünerek kendi varlığını, mutlak ve müstakil bir varlık olarak algilıyorsa; bu Mevlânâ'ya göre bir anlamda insanın, kendi aklı ve iradesi ile ayağına pranga vurmasıdı̊" (Küçük, 2009: 56). Bu bağlamda tasavvufta benlik gömleğinden geçip kul/abd olma bilinci ön plana çıkmaktadır. Klasik şiirde görülen fahriyelerde benliğin ön plana çıkarılması, kişinin kendini üstün görmesi tasavvuf anlayışındaki mahviyet ile bu açıdan bakıldığında iki zıt kutup olarak görülür.

\section{Hayâlî'nin Divân'ında Tefahür}

Hayâlî̀nin tefahür beyitleri, tüm klasik şairlerin divanlarında olduğu gibi Cahiliye Arap şiirinden tevarüs edegelen kasidenin fahriye bölümünde karşımıza çıkar. Belli bir gaye güdülerek kaleme alınan kasidelerde şair, önce memduhunu över, ardından da kendi şairlik yönünden, büyük şairlerden üstün oluşundan, kendisinden daha büyük bir şair olmadığından, adları tarihe geçmiş kendisinden önceki şairlerin olmasının kudretinden bir şey eksiltmediğinden bahsederek kendisini över. Bu övgü, şairin gazellerinin makta beytinde de karşımıza çıkmaktadır. Gazellerin özellikle mahlas beyitlerinde, bazı şairlerin kendilerini övmesi bu manada küçük bir fahriye parçacığı sayılabilir (Pala, 1995: 177). Bu bağlamda Andrews'in de belirttiği gibi çoğunlukla gazelin son beyti olan mahlas beyti, şairi tanıtma işlevi görmekle kalmamış, ayrıca şairin bir parça fahriyeye girişmesine de imkân sağlamış olur (Andrews, 2009: 206). Şair, mahlasından hareketle kendisinin birçok büyük şairden üstün olduğunu vurgular, bazen de Arap ve Fars şiirinin büyük şairleriyle boy ölçüşmeye girişir.

Kanunî Sultan Süleyman'ın nedimliğine kadar yükselmiş, onunla yakın dostluk kurmuş ve bu sayede tezkirelerin anlata anlata bitiremedikleri ihsanlara nail olmuş bir şair olan Hayâlî, yüzyılın Bâkî öncesi en büyük şairlerinden olması ve tezkirelerde döneminde önde gelen şairlerden sayılması ve Hafız-ı Şirazî’ye benzetilmesi, şiirin usul ve inceliklerine vakıf, maharetinin var olması, şiirlerinde tatlı ahenkli, fasih ve selis olup özellikle tasavvufa ziyadesiyle mütemayil olması, döneminde "sultânü'ş-şuârâ-yı Rûm" olarak anılmış olması (Tarlan, 1992: 21; Mengi, 2013: 168) onun ne kadar takdir edilen bir şair olduğunu göstermesi bakımından önemlidir. Şair, bütün bu övgülerin farkında olup övgülerin onun sanat kudretindeki yüceliğine yapıldığının da bilincinde olduğundan -haklı olarakşiirlerinde kendi şairlik dehasıly övünmesine ve birçok beytinde bunu doğrudan dile getirmesine neden olmuştur. Aşağıdaki beytinde şair, şiirini ipe serilmiş incilere benzeterek şiirlerinin ancak denizlerin dilinde/gönlünde -mecazen gönlü deryalar kadar coşkun gönül ehli, derya gibi insanlar- söyleyebileceğini söyler. Yani şair eserlerinin ancak derya gönüllü insanlar tarafından takdir edilebileceğini ima etmekte olup şiirinin ihtişamı karşısında parlak incilerin şiirinin kölesine dönüştüğünü söyleyerek şiir sanatındaki gücünü izaha çalışı: 
Dürr-i nazmum gördü deryâlar dilinde söylenir

Ey Hayâlî bende oldu lü’lü-i lâlâ bana (G. 16/5, s. 94)

Hayal ürünü kurgulardan oluşan bu beyit, şairin kendini övme (fahriye) sadedinde söylediği bir söz olmakla birlikte, aynı zamanda bir hakikati de ifade etmektedir. Kalender bir derviş olarak İstanbul'a gelen şairin inci gibi parlak ve güzel sözleri kısa zamanda başta padişah olmak üzere nice derya gönüllü insan dilinde söylenir olmuş, yani tam anlamıla bir servet sahibi olmuştu" (Şentürk, 2013: 255). Şairin bu hızlı yükselişi, onu çekemeyenlerin saldırılarına uğramasına neden olmuştur. Hayâlî, tüm bu saldırılara şiirdeki kudretiyle cevap vererek kendisine yapılan eleştirileri 'cefa taşı'na benzetmiştir. Yapılan ayıplamaları hak etmediğini, hüner sahibi olduğunu dile getirmiștir. Şair meyve, taş, ikilisini bir arada kullanarak "meyveli ağacı taşlarlar" atasözüne telmihte bulunmuştur. Beyitteki anlamsal uyuma bakıldığında bal arısı manasına da gelen "nahl" sözcüğünü kullanmıştır. Bal arısı, değişik çiçeklerden topladığı nektarla balı oluşturur. Şair tüm bu kurgu içinde kendini belagat meyvesini ortaya çıkaran bir hüner arısı olarak tanımlayıp tefahürde bulunur:

\section{Cefâ taşın ta'n atsa Hayâlî sana alçaklar}

$$
\text { Belâgat mîvesin peydâ eden nahl-i hünersin sen (G. 412/6, s. 232) }
$$

Şair, şiir sanatı konusundaki başarısına dair iddialarını makta beytinde dile getirirken sözünü "sihir" üzerinden anlatmaya çalışır. Şair, şiirle sihir arasında ilişki kurar ve her sözünün sihirle aynı etkiyi yarattığını ifade eder. Şair, "şöyle bir konuştuğumda cihân ebkem kesilir" diyerek şiir sanatındaki başarısını dile getirir. Nitekim sihirbazların yaptıkları hareket ve hilebazlıklar karşısında insanlar hayret içinde kalmakta ve şaşkınlıkla sihirbazları seyre dalmaktadır. Burada cihandan kasıt içindeki insanlar manasındadır, hatta kendi dönemindeki şairleri kast etmektedir ki cihan kelimesinin istimaliyle mecaz-i mürsel yapılmıştır. Şair, konuştuğu vakit insanların güzel sözlerinin yarattığı hayranlıktan sessiz, dilsiz, konuşamayan bir şekle girdiğini anlatmaktadır:

Şöyle gûyâyem ki yanumda cihân asmâtdur

Geh dilümden sihr câri gâh narencâtdur

(Muaşşer 3, s. 67)

Hayâlî’nin şiirlerinde kullandığı kelimelerden ve bu kelimelerin şiirdeki kullanımından hareketle poetik söylemi bağlamında tefahürü yedi başlık altında ele aldık.

\section{1. Şairlik Dehası Üzerinden Yaptığı Tefahür}

Hayâlî’nin tefahürünün en önemli ayağını, şairlik dehası oluşturur. Şiirin bir Tanrı vergisi olduğu ve bu sanatın ancak seçkin kulların kalbine ilham edildiği görüşünü tüm klasik şairler gibi Hayâlî de şiirlerinde dile getirir. Zira klasik şiirde ilahi ilhamın bir parçası olan şiir, Allah'ın seçkin kullarına bir bağışı olarak kabul edilir. Bu da fahriye bölümlerinde tab' ve tabiat ile ifade edilmiştir. Şairlerin 
doğuştan birtakım sanat zevk ve yeteneklerine sahip olma durumu fahriyelerde olduğu gibi tezkirelerde de üzerinde çok durulan kavramlardan biridir (isen Durmuş, 2007: 112). Tezkirelerde yer alan sanatın yaratııışla ilişkisini ele alan Kılıç’a göre "tab" sözcüğü, 17. yüzyıl tezkirelerinde şairin yaradılıș hâlini ifade eden kelimelerin başta gelenidir. Lügatlerde "tabiat, huy ve yaradılış" olarak anlamlandırılır ve tezkirelerde bu genel kullanımın dışında sanatla ilgili, sanata meyilli, sanat zevk ve kabiliyetine sahip oluş hâli gibi özel bir anlam kazanarak doğrudan doğruya şair yaradılışı karşılar (Kıılıc, 1998: 252).

Hayâlî, tefahürün asıl yönünü oluşturan şairlik yeteneğinin Allah tarafından kendisine lütfedilmiş olduğuna dikkat çekerek sanatını ilahi takdirin parçası kabul eder. Zira ilahi takdir, peygamberlikte olduğu gibi sadece seçkin kullara bağış olduğundan şair, kendini Allah tarafından seçilmiş kişi olarak görüp tefahürde bulunur. Ona göre $o$, nice paşaların içinden çıkıp şiir sanatının önde gelenlerinden olmuştur. Elbette ki seçilmiş olma ve ilahi ilham sonucu şiir yazmanın, diğer şairlerle ve yazdıklarıyla mukayesesi mümkün olamayacaktır. Şair, ikinci beyitte bunu "çeşme" metaforu ile anlatarak şairliğinin ilahi bir kaynaktan beslenen bir çeşme olduğunu söyler:

Sen nice paşaların içre ser-âmedsin begüm

Ehl-i nazmın bu Hayâlî öyle bir mümtâzıdur (G. 83/5, s. 118)

Tab-ı Hayâlî menba'ı ayn-ı ilâhîdür

Mâhileri çıkarsa n'ola âşinâ sana

Şair, aşağıdaki beyitlerinde şairlik yeteneğine dikkat çekerken bunu "kelâmullah-ı nâtık, lutf ve kân-ı 'atâ" kavramlarıyla ele alır. Ona göre şairlik, kendisine lütfedilmiş hediyeler kaynağı, kendisi de Allah'ın sözünün söyleyicisi olmuştur. Ona takdir edilen bu deha sayesinde hem kendi döneminde herkesin övünç kaynağı olmuş hem de on sekiz bin âlem kendi şiirinin anlamını ortaya koymak için yaratılmış bir tefsire dönüşmüştür:

Ey Hayâlî bana lutf ideli ol kân-ı 'atâ

Fahr-ı eyyâm bugün tab'-ı güher-bârumdur (G. 121/5, s. 131)

Ey Hayâlî biz Kelâmullâh-ı nâtık olalı

On sekiz bin 'âlem olmuşdur bizüm tefsirümüz $\quad$ (G. 4/5, s. 196)

Şair, şairliğin sonradan öğrenilen bir meslek olmadığına özellikle dikkat çekerken kendisinin şairliğe on dört yaşındayken başladığına da temas etmeden duramaz ve ilahi takdirin sonucu olan yeteneğini memduhuna hissettirmek için tefahür yapar. Şairin kullandığı "tâb” kelimesi sözlüklerde güç, kuvvet, takat manalarına gelir. Asıl olarak şairin burada vurguladığı şairlik tabiatıdır. Şair, şairlik kudretine göndermede bulunarak vezinli şiir okumadaki kuvvetini, Selmân'ın 
dilinin serveti olduğunu ve kendisinin zamanının Selmân'ı olduğunu ifade ederek şairlik yönünü övmüştür:

Ey Hayâlî çârdeh-sâle dahi bir tıfl iken

Tab'-ı mevzûnunla oldun nakd-i Selmân-ı zemân (G. 9/5, s. 303)

Şair, başka şiirlerinde de genç yaşta şiir söylemekle ve genç yaşına rağmen söz ülkesinin emiri olmakla övünür. Hayâlî, yukarıdaki beyitte olduğu gibi çocukluktan beri şiir yazdığına gönderme yaparak 'şehâ' diye bir girizgâhla başlamış ve çok genç yaşta şairlik dehasıyla söz ülkesinin padişahı olduğunu vurgulamıştır. Böylece şair, söz endazesine kendisini koyarak sözdeki olgunluk ve mükemmelliğini şiirdeki emârelerle arz etmiştir:

Şehâ zemânede ben ol suhân-verem ki bugün

Dahi cevân iken oldum emir-i mülk ü kemâl ～(Kaside 10/19, s. 42)

Şair, bazı beyitlerinde doğrudan şairliğin kendi tabiatının bir parçası olduğunu söylemese de kullandığı teşbihler, onun şairliğini nasıl değerlendirdiğini ve şairliğine nasıl bir anlam yüklediğini anlamamızda bize yardımcı olur. Hayâlî, aşağıdaki beytinde kendi şairliği ve şiirleri hakkında bir değerlendirme yaparken kendisini kanaât ve tecerrütten kanatları olan, kutsal mana kuşlarını avlayan bir doğana benzetir. Murgân-ı kudsî, kutsal kuşlar diye çevrilen bu ifade, melekleri anlatmak için de kullanııır. Bu ifade, eşyanın "ayân-ı sâbite"sindeki hakikati anlamında" (Kurnaz, 2001: 227) olup şair, bu kutsi manaları hayali kanatlarla avlayan, yani ilahi sırları varlı̆ı̆ı hakikatinde görüp şiirsel forma sokan kimse olduğunu "doğan" kuşu üzerinden anlatır:

Suhan şehbâzıyam mürgân-ı kudsîler şikârumdur

Kanâ'atle tecerrüdden Hayâlî perr ü bâlüm var (G. 141/5, s. 137)

Hayâlî, şairlik dehasını daha etkili anlatabilmek amacıyla onu değişik imgelerle anlatır; ancak bu imgeler içinde onun kendi övgüsünü en güzel şekilde yansıtan "padişah" imgesidir. Zira şair, aşağıdaki beyitlerde de görüleceği gibi sözü bir ülkeye, kendisini de bir padişaha benzeterek şairliğinin ve şiirinin kıymetini izah etmeye çalışır ve şiirdeki yeteneğiyle övünür:

Pâdişâh-ı mülk-i ma'nîdür Hayâlî derdi ger

Şi'r-i pür-sûzum göre-idi Husrev-i şî̂n-suhan (G. 425/5, s. 237)

Hüsrev-i mülk-ü suhan oldı Hayâlî gözün aç

Deme anun gibi bir sâhib-i divâneyem ben （G. 437/5, s. 241)

N’ola tutsa Hayâlî ‘âlemi tîg-i zebâniyle

Suhan meydânınun çâpük-süvârı pehlevândur bu (G. 461/5, s. 249) 


\subsection{Anlamın Orijinalliği Bağlamında Tefahür}

Şairin diğer şairlerden üstün olduğunu iddia ettiği makta beyitleri ile fahriye bölümlerinde tefahür sebebi olan asıl unsurların başında şairin ortaya koyduğu anlamın orijinal oluşu gelmektedir. Şairin tefahürde bulunduğu orijinallik hususu, ele aldığı konunun daha önce kimse tarafından ele alınmaması, ortaya koyduğu anlamların kendisi tarafından bulunmuş olması, yeni hayallerle şiirini süslemiş olması ve şiirde yer verdiği düşüncenin katışıksız olmasıyla ilgilidir. Şair, anlamsal orijinalliği vurgulamak için şiirlerinde "âb-dâr, gevher-i irfân, şâhid-i ma'nâ, şi'r-i rengîn, nazm-ı rengîn, hakîkat nüktesin, nükte-şinâs, nükte-dân, ma'nî mülk, şi'r-i hayâl-engiz"gibi ifadelerle anlatmaya çalışır. Zira klasik şiirde orijinalliği karşılayan bu sözcükler, belli bir standarda bağlamak zor olsa da lafz, nazm, suhan, şi'r gibi çeşitli kelimelerle birlikte kullanılan pâk, temiz, arı, katışıksız, anlamlarını; endîşe orijinal düşünce anlamını; ter ve taze, kilk, nazm ve şi'r kelimeleri ile birlikte kullanılarak yeni anlamını; rengîn ise, orijinal fikir anlamında kullanılmakla birlikte, renkli, parlak, latif, güzel, hoş anlamlarını da karşılamaktadır (İsen Durmuş, 2007: 110). Şairin şiirlerinde orijinalliği esas aldığını bildirmesi onun poetikasını anlamamız hususunda da oldukça önemli olmaktadır. Zira şair, aşağıdaki beytinde başkasından manalar almadığını, bir doğan gibi orijinal anlamları kendisi avladığını söyleyerek orijinal anlamlar peşinde koştuğunu açıkça dile getirir ve özgün bir şair olduğunu vurgular:

Tab'-ı Hayâlî ma'nî-i gayrı alup n’ider

Şehbâzdur ki sayd özü eyler şikârını

Şair, aşağıdaki iki beytinde şiirlerindeki anlamsal orijinalliğe dikkat çekmektedir. İlk beyitte şair, şiiriyle memduhu arasındaki ilişkiden hareketle şiirindeki anlamsal orijinalliğe dikkat çeker. Şair, memduhuna "Sen ülke tahtının sultanı olduğundan beri dilimin kılıcıyla mana ülkelerini fethettim” diyerek şairlik kudretini memduhuna bağlasa da aslında şair, kendi şiir sanatına dikkat çekmekte, şiirinin mana bakımından ne kadar orijinal olduğu hususuna parmak basmaktadır. İkinci beyitte ise şiirinin gördüğü takdire dikkat çekmektedir. Şaire göre şiirinin "ehl-i sühan" tarafından takdir edilmesi, onun şiirlerinin taşıdığı yeni hayallerden ileri gelmektedir:

Ma’ânî mülkünü tîg-i zebânum birle feth itdüm

Olaldan pâdişâhum sen serîr-i mülk sultânı （Kaside, 14/28, s. 48)

Ey Hayâlî işidüp şi'r-i hayâl-engîzümi

Âferin ehl-i suhanlar bana tekrâr itdiler （G. 140/7, s. 137)

Hayâlî’nin şiirinde orijinalliği ifade eden kavramların başında "nükte-şinâs ve nükte-dân" sözcükleri gelmektedir. Şair, bu sözcükleri çeşitli bağlamlarda kullanarak şiirindeki anlamsal orijinalliğe dikkat çekmeye çalışır. Örneğin aşağıdaki ilk beyitte şair, nükte-şinâslık ve remmal kavramlarını kıyaslayarak kendi 
şairliğini izah etmeye çalısıır. Şairlik, yukarıda da dile getirdiğimiz gibi Allah vergisi olan bir sanattır ve her kula nasip olmamakla beraber ilahi hakikatleri şiir şeklinde ortaya koyar. Remmallik ise kum ve yıldızların şekillerinden hareketle gelecek hakkında bilgi verir. Ancak şairlik, ilahi bir takdir olması hasebiyle remmalden üstündür ve üstelik i̇slam'da gaipten haber vermek küfürken şairlik, peygamber iltifatına mazhar olmuş helal bir eylemdir. Bu anlamda şair, şairlik yönüne vurgu yaparak kendisine yıldızların şekillerindeki müşkülatları arz edilmemesini kendisinin bir remmal değil de nükte-şinas bir şair olduğuna dikkat çeker. Diğer beytinde ise memduhuna seslenerek eski bir kölesi olduğunu onun gibi cihanda nükteleri bilen bir söz ustasının olmadığını söyler:

'Arz itme bana 'ukde-i eşkâl-i nücûmu

Nükte-şinâsem beni remmâl mi sandın

Hayâlî bende-i dîrînedür lutfun dirig itme

Anun gibi suhan-perver cihânun nükte-dânından (G. 420/5, s. 235)

Şairin dikkat çektiği anlamsal incelik ve orijinallik, onun yeni konuları bulup işlemesinden kaynaklı olmayıp onun asıl orijinalliği tefahürünün de asıl noktasını oluşturan hakikati ifade etmesindendir. Zira klasik şiirde şiirin gayesi salt orijinal manalar ortaya koymak olmayıp şiirin asıl gayesi olan aşkın âlemin hakikatlerini şiirsel dille haykııırken bu hakikati kimsenin ifade etmediği tarzda ve yepyeni bir anlamla aktarmaktır. Varoluşun hakikatini, şiirsel formda orijinal manalarla ifade etmek, şairin şairlik kudretinin bir parçası olduğundan tefahürün de asıl kaynağıdır. Bu yüzden şair, her mısrasının hakikatin ince anlamlarını içinde barındırdığına dikkat çeker:

Hayâlî nazmınun bir mısra'ından behremend ol kim

Hakîkat nüktesin söyler bunun birdür çoğu azı （G. 641/5, s. 312)

Şair, tefahürünü İran edebiyatının en büyük mutasavvıf şairi Molla Câmî üzerinden yapmaya çalışır. Şairlik kudreti ve şiirlerindeki derin tasavvufî manalarla kendini tüm İslam âlemine kabul ettiren Molla Câmî gibi büyük bir şair tarafından kabul görülmek ve takdir edilmek, ancak büyük şairlere mahsus olduğunun bilincinde olan Hayâlî, kendi şiirlerini Molla Câmînnin Câm şehrinde işitse kendisine "söz ülkesinin padişahı" diyeceğini söyleyerek tefahürde bulunur. Şair, kendisine verilen "sultân-ı şuârâ-yı Rûm" unvanına göndermede bulunurcasına bu unvanın Molla Câmî tarafından kendisine verilmesini şiirinin rengin oluşuna bağlar ve şiirindeki anlamsal orijinalliğe dikkat çeker:

Ey Hayâlî bana dirdi Husrev-i mülk-ü suhan

Şeyh Câmî şi'r-i rengînüm işitse Câmda

Şair, önüne durmadan engel çıkaran, eleştiren şairlerin kendisine bu kadar saldırmasının sebebini de tefahürün bir parçasına dönüştürerek şiirlerin içerdiği 
orijinal anlamın bir sonucu olduğunu ifade eder. Ona göre gazellerinin anlam olarak taze/yeni olduğundan ve kendisi de mana sevgilisini avladığından düşmanları/diğer şairler tarafından sürekli saldırıya uğramaktadır:

Beyti ocagına su koyan cümle şa'irün

Cânâ Hayâlînün gazel-i âbdârıdur

(G. $88 / 5$, s. 119.)

Ey Hayâlî şâhid-i ma'nâyi sayd itdün velî

Her tarafdan sana sanma ta'ne-i agyâr yok (G. 244/5, s. 173.)

\section{3. Üslubun Güzelliği Bakımından Tefahür}

Şairin tefahüre konu olan özelliklerinden biri de onun üslubudur. Klasik şiirde şairler, "sözün misk dolu olması, hayalin nazik olması, şiirin bir bütünlüğünün bulunması ile beraber yumuşak, hoş, güzel manalarına gelen latîf; ifadenin kusurlu olmaması anlamını karşılayan fasîh; sözün akıcı olması anlamına gelen selîs; parlak, güzel, gösterişli manasındaki garrâ; hoş, hüsn, pâkize, rengîn gibi farklı kelimelerle kullanılan edâ, sözün etkili yani pür-sûz olması gibi çok çeşitli örneklemeler"(İsen Durmuş, 2007: 111) gibi ifadelerle kendi üsluplarındaki başarıyı ifade ederek tefahürde bulunur. Hayâlî de şiirlerinde benzer ifadeler üzerinden kendini başarılı kılan üslubuna dikkat çekmeye çalışmaktadır. Şair, üslubu üzerinden tefahüre giderken fahriye ve maktalarında "hüsn-ü edâ, şi'r-i hayâl-engîz, şi'r-i hasen, şi'r-i nâzenîn, rengîn edâ, pür-sûz" gibi ifadeleri kullanır. Tüm bu ifadeler, şairin üslubunun güzelliğini ve üstünlüğünü, aynı zamanda da diğer şairlere göre daha iyi bir şair olduğunu ifade etmek içindir. Şair, aşağıdaki beyitte iyi bir şair olmayı güzel edasına/üslubuna bağlar:

Biz ey Hayâlî sûhte-i sûz-ı Hüsrevüz

Hüsn-i edâda lîk senâ-gûy-i Şâhîyüz ～（G. 204/5, s. 159）

Şair, aşağıdaki iki beytinde şiirine görülen rağbete üslubu üzerinden tefahürde bulunur. Şair, iki beytinde de şiirinin iyi bir şiir oluşunu ve rağbet görüşünü üslubuna bağlamaktadır. Ona göre şiirinin Rûm ülkesinin padişahının takdirini kazanmasının ve kendisinin mana ülkesinin padişahı olarak tanımlanmasının asıl sebebi üslubundaki güzellik ve şiirindeki yakıcı edadır:

Ey Hayâlî yine bu şi'r-i hasen üslûba

$$
\text { Umarın Hüsrev-i Rûmun sana tahsîni ola （G. 18/5, s.95） }
$$

Pâdişâh•ı mülk-ü ma'nîdür Hayâlî dirdi ger

Şi'r-i pür-sûzum göre idi Hüsrev-i şî̂în-suhan

Şaire göre sanatlı söyleyişler, insanın gönlünü ferahlattığından şiir, sanatlı olmalıdır. Hatta şair, aşağıdaki ilk beytinde sanatlı edayla yazdığı şiirlerine sürekli bakıp ferahladığını söyleyerek kendi şiir sanatıyla övündüğünü ve şiirindeki üstün sanat kudretinden dolayı nazenin şiirlerini bir araya getirip defter ve divanlar 
oluşturduğunu söyler. Ancak şair, sadece sanatlı söyleyişlerin tek başına bir şiiri başarılı kılamayacağının da bilincindedir. Bu yüzden şair, ikinci beytinde sanat kudretini sadece söz sanatlarını kullanarak elde etmediğini, teşbihin şiire süs katmadığını söyleyerek şiirde asıl olanın üsluptaki güzellik olduğuna dikkat çeker:

Hayâlî nakşına bakup güşâde olmaga dâ'im

Bu şi'r-i nâzenînüm defter ü dîvâna tapşırdum ～（G. 362/5, s. 215）

Teşbîh sâde vermez zînet söze Hayâlî

Rengîn edâ gerekdür eş’âr-ı dil-güşâda $\quad$ (G. 471/6, s. 253)

Hayâlî, üslubunun güzelliğine vurguda bulunduğu gibi üslubunun kendine has olduğuna da dikkat çeker. Hayâlî, bunu Nevâyî üzerinden anlatır. Zira Nevâyî, klasik şairler tarafından tarz sahibi üstat bir şair olarak kabul edilmiş ve birçok şair, onun tarzında şiirler kaleme almıştır. Hayâlî, söylediği şiirin üslubundaki renkliliğin kendisine has olduğu, Horasan halkının onun şiirlerini Nevâyî tarzı sanmamaları konusunda uyarır:

Söz sözü rengîn edâ itmek Hayâlî ihtirâdur

$$
\text { Horasan ehli sanmasın bunı tarz-ı Nevâyîdür ～(G. 84/5, s. 118) }
$$

\section{4. Şairin Kendisini Diğer Şairlerle Kıyaslaması Açısından Tefahür}

Hayâlî, kendisinin diğer şairlerden üstün olduğunu iddia ederken başvurduğu yollardan biri de kendini Arap şairlerden Hassan, İmrü'l-Kays; Fars şairlerden Hafız, Molla Câmî, Selmân, Hüsrev-i Dehlevî, Nizâmî, Attar; Türk şiirinin büyük şairlerinden Necâti ve Ali şîr Nevâyî ile mukayese etmektir. Bu kıyas, kendini diğer şairlerden üstün olduğunu kabul ettirme amaçlı olup 15. yüzyıldan başlanarak klasik şairlerin üstünlük iddiasında bulunurken genelde kullandıkları bir yöntemdir. Şairler, kendilerini İran ve Arap edebiyatının büyük şairleriyle karşılaştırarak sanatları itibariyle bu şairlerden üstün olduklarını ya da bu şairler, hayatta olsalar kendilerini takdir edeceklerini söyleyerek tefahürde bulunur. Klasik şairler, bu kıyaslamaya giderken genelde dil açısından taze, orijinal, parlak, seçkin ifadelere sahip olmakla övünmüș ve kıyaslamayı bu noktalar üzerinden sürdürmüştür (Şen, 2014: 48). Hayâlî de aynı yolu takip ederek kendini şöhret sahibi şairler üzerinden över. Aşağıdaki beyitlerinde şair, kendisini Peygamberimizin de takdirine mazhar olan meşhur şair Hassan'a benzeterek iyi bir şair olduğunu ve şairliğinin ölçütünün de bu olduğunu ortaya koymaya çalışır:

Eşigin Ka’be-i hâcât-ı âlem

Hayâlî Ka'bede Hassâna benzer (Kaside, 18/21, s. 55)

Ka'be hakkı pâyen olmuşdur fesâhat minberi

Ben Hayâlî Hazret-i Hassâna benzetdüm seni (G. 603/7, s. 299) 
Şairin tefahürde kıyas unsuru olarak kullandığı Arap şairlerden bir diğeri ise Cahiliye devrinin ve kaside geleneğinin tartışılmaz en büyük şairi İmrü'lKays'tır. Şairin yaptığı kıyas, benzerlik üzerinden olup Ukayz Panayırları'nda düzenlenen şiir yarışmalarına gönderme vardır. Yedi Askı/Mu'alakatü's-Seb’a'da ismi her zaman üst sırada yer alan ve şiirleri Kâbe kapısına asılan İmrü'l-Kays, şiirlerinde Arap fesahat ve belagatinin tüm özelliklerini barındırdığından adı Arap edebiyat tarihinde unutulmazlar arasında yer almıştır. Şairin kıyası tam da bu noktada olup sahip olduğu fesahatle İmrü'l-Kays gibi şöhret sahibi olduğunu ve şiirlerinin Kâbe kapısına asılması gerektiğini söyler:

İmr'ül-Kays gibi oldu Hayâlî hakkın

Bu fasâhatle der-i Kâ'beye asmak kâgıd (G. 46/5 s. 105)

Hayâlî, divânında tefahürde bulunurken kendisini benzettiği ve bir kıyas unsuru olarak ele aldığı şahsiyetlerden biri de İran edebiyatının en büyük mutasavvıf şairi Molla Câmî olup şair, şiirlerinde onu üstat kabul eder. Bazı şiirlerinde ise onunla denk tutarak kendini 'Câmî-i sânî' diye vasıflandırır:

Suhan bezminde ben bir rind-i dürd-âşam kopdum kim

Ma'anî camını içmekde oldum Câmî-i sânî （Kaside 14/29, s. 48)

Ancak şair, her ne kadar onu üstat bilse de kendisini şiir sanatında Câmî'nin takdirine mazhar olacak kadar büyük bir şair sayar. Önceki bölümde verdiğimiz beyitte şair, şiirlerini işittiği takdirde Câmî tarafından "husrev-i mülk-i suhan" kabul edileceğini söyleyerek tefahürde bulunsa da bununla yetinmeyerek aynı zamanda şiirinin onu hayran bırakacağını da iddia eder. Kendi şiirini yüksek bir yere yerleştiren şaire göre şiirlerini Câmî ile Nevâyî işitse şiirlerine hayran kalacaktır:

\section{Ger bu nazm-ı rûh-ı Câmîyle Nevâyî işide}

Uyanup hâb-ı ademden olalar tekrar mest (G. 29/8, s. 99)

Hayâlî’nin tefahürünün kıyas unsurunu oluşturan bir diğer şair, İran edebiyatının tanınmış şahsiyetlerinden Selmân'dır. Hayâlî, Selmân'a atıfta bulunurken hem üslubu, hem şöhreti hem de onutakdir etmekle beraber ondan daha başarılı olduğuna göndermede bulunur. Hayâlî, padişahın iltifatlarının onu “Rûm'un Selmân'ı" yaptığı gibi, üslubunun Selmân'ın üslubuna benzediği ve söylediği sihir dolu şiirlerle Selmân'ın ruhunu zinde kıldığına da göndermede bulunur ve böylece şöhret sahibi bir şair üzerinden ne kadar büyük bir şair olduğunu anlatmaya çalışır: 
Gâfil olma ey Hayâlî nazmına inkâr iden

İltifât-ı Şâh anı Rûm içre Selmân eyledi

(G. 595/5, s. 296)

Nevâyî ger işitse idi nevâ-yi bülbül-i tab’un

Diye idi yahşırak duymuşdur ol üslûb-ı Selmânı (Kaside 14/31, s. 48)

\section{Benem ol sâhir-i suhan-perdâz}

Ki eyledüm zinde rûh-ı Selmânı

(Kaside 16/27, s. 52)

Hayâlî, sözünün ölçülü oluşu yönüyle övünürken şiirini Câmî ve Hafız'ın şiiriyle kıyaslar ve şiirinin kemali bakımından kendisini Selmân ile bir tutar:

Hâfız u Câmi kelâmı gibi mevzundur sözün

Şahlar içre kemâl-i nazm ile Selmân mısın? （Kaside, 20/18, s. 57)

Mutasavvıf şair Attar ve eseri Mantık'ut-Tayr da şairin tefahür amaçlı başvurduğu unsurlardandır. Şair, tefahürde bulunurken herkesin kendi şiirini anlayamayacağını; şiirinin kıymetinin anlaşılması için Attar gibi olmak gerektiğini söyleyerek şiirinin ve şairliğinin değerini ifade etmeye çalışmaktadır:

Mantık'ut-Tayr oldı her beyti Hayâlînün velî

Kuş dilin fehm eylemez her kim ki Attar olmadı

(G. 633/5, s. 309)

Hayâlî, tefahürde bulunurken "söz mumunu aşk ateși ile yakmakla ve Hüsrev-i Dehlevî kadar büyük bir şair olmakla” övünmektedir. Zira Hüsrev, yaşadığı dönem itibariyle şöhret sahibi bir şair olup ünü kendinden sonraki şairlere kadar ulaşmıştır. Hüsrev'in bu özelliğinden dolayı Hayâlî de kendisini yaşadığı asrın Hüsrev'i olarak kabul etmiştir. Şair, istifham sanatına başvurarak "Hüsrev gibi zamânede fâyık degül miyem?" diyerek cevap beklemeksizin diğer şairlerden üstün olduğunu tasdik etmiştir:

Sûzumla söz çerâgını yakdum Hayâlî ben

Husrev gibi zemânede fâyık degül miyem (G. 374/5, s. 219)

Hayâlî'nin kıymet verdiği Türk şairlerin başında Nevâyî ve Necâtî gelmektedir. Nevâyî, Türk edebiyatının en büyük şairi olarak kabul görürken Necâti, Hayâlî'nin yaşadığı yüzyılda üslup sahibi usta bir şair olarak kabul edilir. Ancak Hayâlî, iki şairin de kendisinden önce gelmiş olmasını şöhretine gölge düşürecek bir talihsizlik olarak görmez. Şair, bunu "gül-diken" tezadı üzerinden anlatır. Şaire göre "gül dalından önce diken, sonra gül bittiğinden" Nevâyî ve Necâtî’nin kendinden önce gelmesi bir üstünlük sayılamaz: 


\section{Sonra geldümse Necâtî ile Nevâyîden ne gam}

Har evvel ser-zened ez şah-u-ba'd ez bar gül (Kaside, 12/24, s. 45)

Şair, başka bir şiirinde ise kendi şairlik kudretini hamse şairlerinden Karamanlı Nizamî üzerinden anlatarak tefahürde bulunur. Ancak şair, bu beyitte hem Karamanlı Nizâmî'yi hem de Nizâmî-yi Gencevî’yi de hatırlatır. Şair, şiirlerinin Karaman'a bir ravi tarafından aktarılsa onun hayat bahşeden şiirinin, Nizâmî’ye taze bir can vereceğini söyler:

\section{Ravî iltürse Karamana Hayâlî şi'rüni}

Bula nazm-ı rûh-bahşundan Nîzâmî tâze cân (G. 381/5, s. 222)

Şair, meşhur şairler üzerinden tefahürde bulunduğu gibi isim vermeden kendi dönemindeki şairlerle kendini kıyaslayarak onlardan üstün olduğu iddiasıyla da tefahüre girişir. Hayâlî’ye göre döneminin şairlerinin şiirleri kendi şiirine ulaşamaz ve "Hayallerde kalan Hayâlî'dir ve geriye kalan, unutulan şairlerin sadece yazılı mısraları olacaktır." Böylece şair, şiir vadisinde kendisini ulaşamaz bir yere konumlandırır:

Eremez şâ’irlerün şi'ri Hayâlî nazmına

Gerçi oldı her biri ser-defteri nazm-ı metin (Kaside 23/ 33, s. 63)

Şair, bazı beyitlerinde bir padişah ve ülke imgesi etrafında şairlik kudretini ve şiir sanatını izaha kalkar. Şair, kendini şiir tahtının sahibi ve Osmanlı mülkünün can vereni olarak görmekle beraber Rûm ülkesinin başkentinde şiir tahtında şairler sultanı olarak da görür. Şair, âb-ı rûh-u mülk" terkibi ile hatıra anlamına gelen "âb-ı rûy" tamlamasına da telmihte bulunarak kendine yüce bir paye biçmek için Osmanlı devletinin yüz suyu olarak da tanımlar:

Ey Hayâlî devletünde Pâdişâh-ı 'âlemün

Pây-i taht-ı Rûmda şi'r ehlinün sultânıyam (G. 354/5, s. 213)

Benem ki nazm serîrinde sâhib-erkânem

Benem ki âb-ı rûh-ı mülk-i Âl-i Osmânem (G. 342 /1, s. 208)

\subsection{Söylediği Nazmın Kıymetini Anlatmada Tefahür}

Hayâlî, şiirlerinde kullandığı Türkçenin ifade gücüyle anlamı başarılı bir şekilde bağdaştırarak şiirleriyle dönemine damga vurmuş ender şairlerden biridir. Hayâlî’nin şiirlerindeki derin mana, ahenk ve zarafet şiirlerine değer katmış ve şiirlerindeki bu özellikler, dönemin diğer şairlerinden üstün olmasını sağlamıştır. Birçok şairin şiirlerine nazireler yazması, onun şiirinin bu ayırt edici özelliğinden ileri gelmektedir. Bunun bilincinde olan şair, her fırsatta şiirinin orijinalliğiyle, ses ve anlam gücüyle tefahürde bulunmuştur. Şair, şairlik şöhretinin sadece Rum/Anadolu ile sınırlı olmadığını, İran ve Turan'a da nam saldığını söyleyerek şiirdeki başarısına ve şöhretine vurgu yapar: 
Rûmda nazm-ı Hayâliyle hem-âgâz olalı

Saldı âvâzeyi İran ile Turana sadak

(G. 249/5, s. 175)

Divân'ında tefahürde bulunduğu birçok özellik havi olup en çok üzerine titrediği konulardan biri de şiirinin kıymetini ortaya koymak amacıyla şiirini değerli madenler üzerinden anlatmaktır. Bunda amaç, şairin şiirine yüklediği değeri renkli hayallerle anlatma yoluna gitmektir. Hayâlî, kendisinin şiirleri dururken şahların başka şairlerin şiirlerini dinlemelerine anlam veremediğini ifade etmek için "lü’lü-yi lâlâya çekmek" tabirini kullanmıştır. Ona göre kendi şiirleri dururken kulağa inciler takmak anlamsızdır:

Eş’âr-ı Hayâlî var iken gûşunu şehler

Bilsem ne içün lü'lü-yi lâlâya çekerler

(G.55/5, s. 108)

Şair, Cahiliye döneminde en iyi şiirlerin Kâbe'nin duvarına asılması geleneğine telmihte bulunarak kendi şiirini değerlendirir. Hayâlî, padişahın kapısını Kâbe'ye benzetir ve kendi şiirini de Seb’a-i Mu'allaka'ya benzetir. Ona göre şiiri, o kadar yüce bir değere sahiptir ki şiiri ikinci Kâbe olan padişahın kapısına asılmalıdır:

Her sözüm Seb’a-i Mu'allâkadur

Dergeh-i Şâh Kâ'be-i sânî

(Kaside, 16/29, s. 52)

Hayâlî̀nin tefahür unsuru olarak kullandığı diğer imgeler ise "derya ve gavvas"tır. Derya, şairin şiirinde imgesel değer olarak yer almasını sağlayan derinliği ve içinde taşıdığı inci, mercan gibi değerli nesnelerken "gavvas" bu değerli incileri çıkaran kimsedir. Şair, ilk beytinde "dalga-deniz" metaforundan da yararlanarak hem tasavvufi boyuta vurguda bulunmuş hem de şairlik dehasını derya ile bağdaştırarak deryada her lahza dalga oluştuğu gibi şairlik kudretinden dalgalar gibi sürekli satırların oluştuğuna vurgu yapmıştır. İkinci beytinde ise şair, kendisini söz denizinin gavvas/dalgıcına benzeterek rüzgârdan habab/kabarcıklar gibi nice düğmeler döktüğünü söyler:

Hayâlînün dili deryâya benzer

Sutûr-ı şi'ridür emvâc-ı deryâ

Hayâlî bahr-i kelâmun olalı gavvası

Habâb gibi nice dügmeler döker yelden

(G. 453/5, s. 247)

Şair, şiirlerinin mevzun ve güzel oluşu itibariyle onu sevgilinin yüzündeki ayva tüylerine, tefekkür ehlinin kabul gördüğü göz nuruna benzetir. Sözlerini göz nuru olarak kabul ederken makbuliyetinin tefekkür ehli tarafından onaylandığını dile getirmektedir: 
Hatt-ı nigâr gibi Hayâlî senün sözün

Makbul-i tab-ı ehl-i nazar nûr-ı dîdedür $\quad$ (G.87/5, s. 119)

Şair, şiirini zevk kadehinin şarabına benzetir ve şarap imgesi üzerinden de şiirinin değerini anlatarak tefahürde bulunur. Bilindiği gibi şarap, klasik edebiyatta rengi, kokusu, sarhoş edici özelliği bakımından sıklıkla teşbihlerle dile getirildiği gibi tasavvufta ilahi aşkın sembolü olmasıyla da şairler tarafından kullanılmıştır. Şairin, beyitte şiirini kadehteki lezzetli şaraba benzetmesi, şiirinin taşıdığı edebi değere ve zevke bir gönderme olup şaire göre bu kadehteki şarabı ancak söz sahibi, ehil kişiler içebilecektir:

\section{Nazm-ı Hayâlî bâde-i câm-ı mezâkdur}

Ancak bu câmı merdüm ü sâhib suhan çeker $\quad$ (G. 115/5, s. 128)

Hayâlî, şiirini misk kokulu söyleyişler, deyişler olarak tabir etmiştir. Hata "(Çin) iklimine şiiri ulaşsaydı eğer Çin'deki güzeller dillerinden düşürmezdi." deyip şiirinin edebi bakımdan ne kadar değerli olduğunu anlatarak övünmektedir:

Vird idinirdi Hayâlî nazmunı hûbân-ı Çin

Ger Hata iklimine varsa bu güft ü gûy-ı misk

Şair, başka bir beytinde ise klasik şiirdeki Cebrail'in etrafında oluşan mazmunlardan faydalanarak şiiriyle Cebrail arasında ilişki kurmuştur. Cebrail mazmunu etrafında şair, güçlü bir anlam katmanı oluşturmak için "ervah-ı kudsiler, şehperin, mekes-ran, şehd" gibi kelimelerden yararlanarak şiirin değerini izah etmeye çalışmıştır. Şair, nazmını şehd'e yani bala benzetmiş, bütün ervah-ı kudsileri/melekleri şiiri etrafında dönen sineklere benzetmiştir. Şair, tatlı üslubu karşısında meleklerin bala üşüşen sinekler gibi etrafına üşüştüğünü, Cebrail’in kanadıyla ona yelpaze olduğunu söyleyerek şiirinin değeri üzerinden tefahürde bulunmuştur:

Oldı nazmum şehdine ervâh-ı kudsiler mekes

Şehperin ana mekes-rân itdi Cibril-i Emin (Kaside, 23/ 38, s. 63)

Hayâlî, şairlik kudretiyle sihir arasında ilişki kurarak sihrin insanı etkileyip büyüsü altına alması özelliğinden hareketle şiirinin etkileyiciliğini anlatmaya çalışmıştır. Sevgilinin dudağını şarap olarak ele alan şair, sevgilinin dudağının şarabını, güzel ve renkli şiiriyle övdüğünü, sihirli söyleyişe sahip bir şair olduğundan dolayı da büyü yaptığını söyler:

Nazm-ı rengînümle vasf itdim şarâb-ı lâ'lini

Sâhir-i nazmem anun-çün ey gül efsûn eyledüm (G. 366/3, s. 217) 


\subsection{Muhteva Bağlamında Hayâlî’de Tefahür}

Şairin şiirin muhtevası hakkındaki fikirleri de şiirini ve şairliğini övmede başvurduğu yollardandır. Şairin şiir sanatını tefahürün bir parçasına dönüştürürken göz önünde bulundurduğu hususlar, sözün değeri ve içeriğidir. Şair, aşağıdaki beyitte sanki “ideal bir şiirin muhtevası nasıl olmalı?” sorusuna cevap ararcasına şiirin muhtevası hakkında açıklama yapar. Şiirin mecazlarla örülü yapısının ötesinde mecazları istimal ederek hakikati bağışlayan bir yapı olması gerektiğini ifade etmiştir. Şair, sözün mecaz ve hakikat penceresinden şiirine bakarak mecazlı şiirler yazdığından dolayı övünür. Hayâlî’ye göre yazdığı şiirler, mecazî olmasına rağmen ilahi gerçekliği/hakikati anlatır. Zira mecaz üzerinden hakikati anlatmak ustalık istediğinden şaire göre böyle bir anlatım, her şairin kârı olamaz:

\section{Şi'r oldur kim mecâz iken hakîkat bahşola}

İrmedi bî-zek ana illâ ki akl-ı dürbîn Hayâlî (Kaside, 23/34, s. 63)

Şairin yukarıdaki beyitte dile getirdiği hakikat, irfanî boyut olup eşyada gizli olan ilahi yüzdür. Şair, birçok şiirinde "hakîkat câmı, hakîkat bâdesi, hakîkat râhı, nikât-ı hakîkat bahri" vb. terkipler kullanarak ideal bir şiirde olması gereken muhtevaya dikkat çeker. Bu bağlamda Hayâlî’ye göre söz içinde gizlenmiş ince nükteler bulunmalıdır ki bu tarzda yazılmış şiirler erbab-ı şiir arasında destan olur. Ancak ince nükteler herkes tarafından anlaşılmadığından şiirde mecaz örtüyle gizlenmiş olan hakikat, ancak tahkikle ortaya çıkar. Şairin şiir üzerinde vermek istediği mesajın ancak tahkikle ortaya çıkan hakikat nüktesini şaire göre öyle içten kullanmak lazım ki her biri destan gibi şöhret bulmalıdır ve aynı zamanda ince nükteli sözlere karşılık da verilmelidir:

Şi'ründe ey Hayâlî nikât-ı hakîkat an

Tâ dôstâna her biri bir dâsitân ola (G. $8 / 5$, s. 91)

Dehânıyla miyânı fikri içre aklı gayb itdüm

Nice ince söze gerçi bu gün hâzır cevâb oldum (G.33/4, s. 212)

\section{Tefahür}

2.7. Dini ve Destani Motiflerle Sözünün Kıymetini Ortaya Koymada

Hayâlî, poetik üstünlük iddiasında bulunup övünürken birçok klasik şair gibi dinî, tarihî ve efsanevî şahsiyete atıfta bulunur. Şair, şiirin kıymetini ifade etmek amacıyla sözün canlara hayat vermesi bağlamında “dem-i İsâ/İsa'nın nefesi”ne, şiirinin anlam ve söz güzelliği bağlamında “Hz. Yusuf”un güzelliğine, sözün değerinin yüceliğini aktarmak için Cahiliye'nin muteber şairlerinin Kâbe'ye asılan şiirlerine benzetmek amacıyla "Seb'â-i Mu'allâka"ya, taşıdığı anlam bakımından Mânî’nin Ejreng kitabına, bir ülke olarak düşündüğünde de kendisini Hüsrev, Rüstem, Dara ve Cem'e benzeterek anlatma yoluna gider. Özellikle İran'ın efsanevî şahsiyetlerine yapılan göndermelerde şair, nazmının ve tarzının 
ne kadar kuvvetli olduğunu belirtmek istemiştir. Ayrıca Mecnun, Ferhad ve Vamık gibi aşk kahramanlarına da göndermede bulunarak aşk konusunda da mukayeseye girer (Şen, 2014: 48).

Şair, tefahürde bulunurken $\mathrm{Hz}$. İsa imgesi etrafında şiir sanatını anlatmaya çalışır. Bunu yaparken de Hz. İsa'nın nefesiyle hastaları iyileştirip ölüleri diriltmesi yönünü beyitte çağrıştıracak şekilde kullanır. Şair, aşağıdaki beytinde şiirinin dinleyenin ruhunu rahatlatması, ona hayat vermesi bağlamıla Hz. İsa'nın nefesinin hastaları iyileștirme ve diriltme yönü arasında bağlantı kurarak tefahüre gitmiş ve şiirinin kudretini ortaya koymaya çalıştığı gibi şiirinin ilahi ilhamın bir parçası olduğuna da atıfta bulunmuştur:

Dem-i Îsa gibi oldı suhanum rûh-efzâ

Kadr ile başum eger göge irerse yeri var (Kaside, 2/21, s. 30)

Şair, şiirinin belagat bakımından güzel oluşuyla Hz. Yusuf'un güzelliği arasında ilişki kurarak şiirini Mısır şehrinin belagatinin Yusuf'u olarak tanımlar. Hz. Yusuf, klasik edebiyatta vazgeçilmez bir manzumdur. Yusuf peygamberin hayatı etrafında oluşan tüm anlamsal çağrışımlardan yararlanan şair, şiiriyle Hz. Yusuf arasında ilişki kurar. Bu amaçla Hayâlî, Hz. Yusuf'un güzelliğiyle tüm Mısır’ı hayran bırakması ile şiirinin belagat güzelliği arasında ilişki kurarak kendisini "Yusuf-ı Mısr-ı belagat" olarak niteler. Şair, Hz. Yusuf'un çocukken satılmasıyla şairlik kudreti arasında ilişki kurarak kendi kıymetini korkusuzca sattığını söyler:

Yusuf-ı Mısr-ı belâgatdür Hayâlî dostum

Anun içün kendüyi kıymetle bî-pervâ satar （G. 69/7, S.113）

Hatem-i Tay da şairin tefahürünün bir parçası olarak şiirlerinde karşımıza çıkar. Şair, bunu yaparken Hatem-i Tay'ın dillere destan cömertliğine vurguda bulunarak ondan kerem aldığını ifade eder. Ona göre her insan bu dünyaya belli bir rolü ifa etmek için gelmiştir. Kendisinin de yaratılış gayesi güzel şiirler söylemektir ki şiirinin şöhreti de Hatem'in kereminden alınmıştır:

Güzeller nâza 'âşıklar niyâza geldi dünyâya

Hayâlî sözle meşhûr oldı Hatemden kerem kaldı (G. 632/5, s. 309)

Yukarıda da belirttiğimiz gibi şair, poetikası üzerinden tefahüre giderken âleme nam salması bağlamında Rüstem, Hüsrev, Dara, Cem gibi şahsiyetlere, bu şahsiyetlerin etrafında oluşan destansı anlatılara ve onların maceralarına atıfta bulunarak kendisini bu şahsiyetlerle kıyaslar ya da onlara benzetir. Aşağıdaki beyitlerde şair, Rüstem'in kendi şairlik kudreti karşısında zebun kaldığını, şiir 
sanatında devrin Dara ve Cem'i olduğunu, kendisinin şiir ülkesinin padişahı olmasıyla şiir ülkesinin Hüsrev’i olduğunu söyleyerek övünür:

Meydan-ı nazmun eyledi Rüstemlerin zebûn •

Kaşd-ı Hayâlî ma'reke-ârâ-yı gîvedür

Bugün devrinde bir Dârâ-yı Cem kadr ü felek tahtın

Hayâlî arsa-i nazmun ser-âmed pehlevânıdur (G. 174/5, s. 149)

Pâdişâh-ı mülk-i ma’nidür Hayâlî dirdi ger

Şi'ri-i pür-sûzum göreydi Husrev-i şîrîn suhan (G.425/5,s. 237)

Şair, tefahürde bulunurken sanatkârlarla veya mitolojik şahsiyetlerle yapılan kıyaslamalarda onların meşhur oldukları yönlere vurgu yapmıştır. Şair, resim sanatının en büyük ustası olan, Erjeng ve Nigâristân adlı kitaplarıyla ün salan Mânî'nin hat çekmesine ve tasvirlerine değinerek üstünlüğünü vurgulamaya çalışır (Şen, 2014: 48). Şaire göre Mânî'nin eserleriyle onun şiirlerindeki tasvir aynı ölçüdedir. Bu bağlamda Şaire göre her beyti Mânî'nin Erjeng ve Nigâristân'ına denktir:

Bozaldan sûret-i Erjengi sen bu nakş-ı dilkeșle

Benüm vasfında her beytüm Nigâristân-ı Mânîdür (G.174 / 2, s. 149)

Bulurdu reng-i tegayyür çu nazır-ı su’bân

Göre-idi hâme-i Mânî-sitânumı Erjeng ～(Kaside, 7/26, s. 37)

Bu Hayâlî oldu Erjeng-i Nigâristân-ı nazm

Mânîyi ko gör ma’âni hüsnünün nakkâşını （G. 638/5, s. 311)

Hayâlî, aşk ve âşıklık ile şiir sanatı arasında ilişki kurup tefahürde bulunurken genelde Doğu edebiyatının büyük aşk kahramanları ile kendini bağdaştırır. Mukayesenin konusu aşktır, aşk, âşıklık ve şiir arasında ilişki kurulur. Şair, aşkının “Mecnûn, Ferhâd ve Vâmık”tan daha büyük olduğunu onların sadece bir isimden ibaret olup adlarını aşk defterinden sildirdiğini söyleyerek tefahürde bulunur (Şen, 2014: 48):

Serîr-i aşkı aldum Vâmık u Ferhâd ü Mecnûnla

Düzüp dîvâneler alayını ben dahı ser çekdüm

(G. 356/4, s. 213)

Nice Ferhâd ile Mecnûnları zencîre çeken

Aşk kişverlerinün mâliki sultânem ben

(G. 437/2, s. 241)

Belâ bezminde Ferhâd ile Mecnûn geçdi ben kaldum

Sorarsan meclisün keyfiyyetin kendün bilenden sor (G. 71/5, s.114) 


\section{Sonuç}

Yukarıda Hayâlî Bey'in poetikası bağlamında yaptığı tefahürlere dair verdiğimiz örnekleri göz önünde bulundurduğumuzda şairin tefahürü şairlik kudreti üzerinden yaptığını ve diğer şairlerden üstün olduğunu ispat amacı güttüğünü görmekteyiz. Şair; tefahürde bulunurken geleneksel mazmunları kullanmış, maharetini bu ortak mazmunlar üzerinden ortaya koymuştur. Hayâlî'de tefahür bağlamında ilk dikkati çeken, şairin kendisini başka şairlerle kıyaslamış olmasıdır. Şair; kendisinden önce yaşamış Arap, Fars ve Türk şairlerle kıyaslamıştır kendisini. Kıyaslamada kendisini yüceltmiş, kıyaslamaya tâbi' tuttuğu şairleri ise kendine denk veya kendisinden aşağı görmüştür. Ancak şairin tefahürde bulunurken salt kendisini övme gayesi gütmediğini, bu beyitlerin aynı zamanda poetik bir değer taşıdığını da unutmamak gerekir. Çünkü tefahür beyitlerinde şair, şiirine bakış açısını yansıttığı gibi aynı zamanda ideal bir şiirin nasıl olması gerektiği, hangi büyük şairlerin örnek alınması veya aşılması gerektiği hususunu da kendi şiirinden hareketle açıklamıştır. Bu tür tefahür beyitlerinin şairin poetikası hakkında da bize bilgi vereceğini, şairin poetikası yazılırken bunlardan hareket edilebileceğini gösterir. Bütün bu değerlendirmeler, bize fahriye bölümlerinin sadece bir övgüden ibaret olmadığını; şairin, kendini narsist bir bakış açısıyla övmesiyle beraber ideal şair ve şiirin nasıl olması gerektiği noktasında da bizi aydınlattığını söyleyebiliriz.

\section{Kaynakça}

Andrews, G. W. (2009). Şiirin Sesi Toplumun Şarkısı (T. Güney, Çev.). İstanbul: iletişim.

Ayverdi, İ. (2011). Misalli Büyük Türkçe Sözlük (2. Baskı). İstanbul: Kubbealtı Neşriyat.

Banarlı, N. S. (1971). Resimli Türk Edebiyatı Tarihi (Cilt 1-2). İstanbul: MEB Basımevi.

Bilkan, A. F. \& Aydın, Ş. (2007). Sebk-i Hindi ve Türk Edebiyatında Hint Tarzı (1. Baskı). İstanbul: 3F Yayınevi.

Çağbayır, Y. (2007). Ötüken Türkçe Sözlük (1.Baskı). İstanbul: Ötüken.

Çavuşoğlu, M. (1986). Kaside. Türk Dili 415-416-417, 17-78.

Çetin, N. M. (2011). Eski Arap Şiiri (1.Baskı). İstanbul: Kapı.

Devellioğlu, F. (1999). Osmanlıca-Türkçe Ansiklopedik Lûgat (3. Baskı). Ankara: Aydın Kitabevi.

Dilçin, C. (2009). Örneklerle Türk Şiir Bilgisi (9. Baskı). Ankara: TDK Yayınları.

Güneş, K. (2010). Arapça-Türkçe Sözlük (1. Baskı). İstanbul: Mektep.

Horney, K. (1994). Psikanalizde Yeni Yollar (S. Budak, Çev.). Ankara: Öteki.

Hökelekli: Enâniyet. (1995). TDV İslam Ansiklopedisi içinde (1. Baskı. Cilt. 2. s. 170171). İstanbul: TDV Yayınları.

İnalcık, H. (2010). Şair ve Patron -Patrimonyal Devlet ve Sanat Üzerine Sosyolojik Bir İnceleme- (3. Baskı). Ankara: Doğu Batı. 
İsen, T. I. (2002). Divan Şiirinde Fahriye. Yayımlanmamış yüksek lisans tezi, Bilkent Üniversitesi, Ankara.

İsen: Fahriye. (2013). Türk Dünyası Edebiyat Kavramları ve Terimleri Ansiklopedik Sözlüğü içinde (Cilt 2. 1. Baskı. s. 427-428). Ankara: AKM Yayınları.

İsen-Durmuş, T. I. (2006). II. Selim Dönemi Sonuna Kadar Osmanlı Edebi Hamilik Geleneği. Yayınlanmamış doktora tezi, Bilkent Üniversitesi, Ankara.

İsen-Durmuş, T. I. (2007). Fahriyeler Işığında Osmanlı Şiirinde İdeal Şairin Portresi, Bilig 43, 107-116.

Kaçar, M. (2006). Şeyh Gâlib'de Tefahhür, Mavi Atlas 1, 105-111.

Kalkışım, M. (2010). Klasik Şiirde Benlik Psikolojisi, Uluslararası Sosyal Araștırmalar Dergisi 3/15, 138-150.

Kanar, M. (2009). Osmanlı Türkçesi Sözlüğü (1. Baskı). İstanbul: Say.

Karadeniz, M. (2012). Gazelleri Işığında Bâkî’de Tefâhür, Turkish Studies 7/3, 16491664.

Kılıç, F. (1998). XVII. Yüzyıl Tezkirelerinde Şair ve Eser Üzerine Değerlendirmeler (1. Baskı). Ankara: Akçağ.

Komisyon. (2005). Türkçe Sözlük (10. Baskı). Ankara: TDK Yayınları.

Kurnaz, C. (2002). Eski Türk Edebiyatı (1. Baskı). Ankara: Gazi Kitabevi.

Küçük, O. N. (2017). Mevlana'ya Göre Manevi Gelişim Benliğin Dönüşümü ve Miracı (1. Baskı). İstanbul: Insan Yayınları.

Levend, A. S. (2017). Divan Edebiyatı -Kelimeler ve Remizler Mazmunlar ve Mefhumlar- (2. Baskı). İstanbul: Dergâh Yayınları.

Mengi, M. (2013). Eski Türk Edebiyatı Tarihi -Edebiyat Tarihi-Metinler- (20. Baskı). Ankara: Akçağ.

Mevlana Celaleddin-i Rumî. (2013). Mesnevi (A. Karaismailoğlu, Çev.). Ankara: Akçağ.

Pala, İ. (1995). Ansiklopedik Divan Şiiri Sözlüğü (3. Baskı). İstanbul: Akçağ.

Parlatır, i. (2009). Osmanlı Türkçesi Sözlüğü (1. Baskı). Ankara: Yargı Yayınları.

Sayar, K. (2000). Sûfî Psikolojisi Bilgeliğin Ruhu Ruhun Bilgeliği (1. Baskı). İstanbul: İnsan Yayınları.

Şen, Y. (2014). Divan Edebiyatında Rekabet. Yayınlanmamış yüksek lisans tezi, Pamukkale Üniversitesi, Denizli.

Şentürk, A. A. (2013). Osmanlı Şiiri Antolojisi (9. Baskı). İstanbul: Yapı Kredi Yayınları.

Tahirü'l-Mevlevî. (1994). Edebiyat Lûgatı (1. Baskı). İstanbul: Enderun Kitabevi.

Tanpınar, A. H. (2011). Edebiyat Üzerine Makaleler (9. Baskı). İstanbul: Dergah Yayınları.

Tarlan, A. N. (1992). Hayâlî Divanı (1. Baskı). Ankara: Akçağ.

Uludağ: Ene. (1995). TDV İslam Ansiklopedisi içinde (1. Baskı. Cilt. 2, s. 232-233). İstanbul: TDV Yayınları. 